\title{
Migratory trophoblast cells express a newly identified member of the prolactin gene family
}

\author{
Dustin O Wiemers*, Rupasri Ain*, Shigeki Ohboshi and \\ Michael J Soares
}

Institute of Maternal-Fetal Biology and Departments of Molecular \& Integrative Physiology and Obstetrics \& Gynecology, University of Kansas Medical Center,
Kansas City, KS 66160, USA
(Requests for offprints should be addressed to M J Soares, Department of Molecular and Integrative Physiology, University of Kansas Medical Center, Kansas
City, Kansas 66160, USA; Email: msoares@kumc.edu) *D O Wiemers and R Ain contributed equally to this work.

\begin{abstract}
Rodents possess an expanded prolactin (PRL) family of genes. These genes encode for a family of structurally related hormones/cytokines that are expressed most prominently in the anterior pituitary, uterus and placenta. In this study, we have identified a new member of the rat PRL family through a search of the National Center for Biotechnology Information expressed sequence database. The cDNA was sequenced and its corresponding mRNA characterized. On the basis of existing nomenclature, the rat cDNA was termed PRL-like protein-N (PLP-N). PLP-N has structural features indicative of its inclusion in the PRL family and is most closely related to PRL-like protein-F (PLP-F) and proliferin related protein (PLF-
\end{abstract}

RP). A survey of PLP-N mRNA expression by Northern analysis indicated that PLP-N showed extensive expression in the metrial gland and minimal expression in the chorioallantoic placenta or other tissues. Expression of PLP-N mRNA was restricted to migratory trophoblast cells. Junctional zone trophoblast cells isolated from day 13 of gestation placenta differentiated in vitro and exhibited a capacity for PLP-N expression. In summary, we have discovered a new member of the PRL family that is prominently expressed in migratory trophoblast cells residing in the metrial gland.

Journal of Endocrinology (2003) 179, 335-346

\section{Introduction}

The prolactin (PRL) family has undergone species-specific expansions, most notably in rodents, and especially in the mouse and rat. This expansion arose from gene duplication events and represents a specialized adaptation to pregnancy (Soares \& Linzer 2001). In the rat, the PRL family consists of at least 19 members, including PRL, placental lactogens (PLs), PRL-related proteins (PRPs), PRL-like proteins (PLPs), and proliferin-related protein (PLF-RP). Genes encoding the PRL family are situated on chromosome 17 of the rat genome (Cooke et al. 1986, Deb et al. 1991c, Roby et al. 1993, Cohick et al. 1996, Dai et al. 1996a,b; Shah et al. 1998). Members of the PRL family are most prominently expressed during pregnancy in the anterior pituitary, uterus or trophoblast cells of the placenta (Dai et al. 2002, see Soares \& Linzer 2001 for a review). Expression is precisely orchestrated in tissue- and gestationally specific patterns for each member of the PRL family (Dai et al. 2002, see Soares \& Linzer 2001 for a review). Two compartments of the chorioallantoic placenta (junctional and labyrinth zones) and three trophoblast cell lineages contribute to the elaboration of the hormones. The junctional zone of the chorioallantoic placenta is situated at the maternal interface and contains trophoblast giant cells and spongiotrophoblast cells. Both trophoblast giant cells and spongiotrophoblast cells contribute to the synthesis of PRL family hormones. Hormone production begins at the ontogeny of junctional zone development and continues for the duration of pregnancy (Dai et al. 2002). During the last week of gestation, a new placental source arises. The labyrinth zone of the chorioallantoic placenta is located at the fetal interface and contains a population of trophoblast giant cells, which produce a unique subset of PRL family hormones (Campbell et al. 1989, Dai et al. 2000, 2002). The temporal- and spatial-specific patterns of hormone production probably have an effect on hormone delivery and the biology of pregnancy. Members of the PRL family target and influence a wide range of maternal targets, including the reproductive tract, liver and other classic PRL targets (Goffin et al. 2002), hematopoietic and immune systems (Lin \& Linzer 1999, Müller et al.1999, Bittorf et al. 2000, Wang et al. 2000, Ain et al. 2002, Yu-Lee 2002) and vasculature (Jackson et al. 1994, Corbacho et al. 2002). Some members act via classical mechanisms involving the 
PRL receptor-signaling pathway, whereas others influence their targets via mechanisms that are at present not well understood.

In this report, we have identified a new member of the rat PRL family through a search of the National Center for Biotechnology Information (NCBI) Expressed Sequence Tag database (EST). We have named this new member 'PRL-like protein-N' (PLP-N). Most interestingly, PLP-N is uniquely expressed in migratory trophoblast cells situated outside the chorioallantoic placenta. These PLP$\mathrm{N}$-positive trophoblast cells penetrate and envelop specialized blood vessels within the metrial gland, a mesometrial compartment of the uterus providing the blood supply to the chorioallantoic placenta.

\section{Materials and Methods}

\section{Animals and tissue preparation}

Holtzman rats were obtained from Harlan Sprague Dawley Inc. (Indianapolis, IN, USA). Both non-pregnant and pregnant rats were utilized. To obtain timed pregnancies, females were caged overnight with fertile males. The presence of sperm in the vaginal smear was designated day 0 of pregnancy. Tissues including uterus, metrial gland and placental tissues were dissected from pregnant animals. Briefly, embryos and placentas with their encapsulating decidual tissue were removed from the uterus. Further dissections were performed with the aid of a dissecting microscope $(\times 10-20$ magnification). The overlying decidual tissue and the underlying yolk sac/umbilical insertion were removed by means of fine forceps and iridectomy scissors. The chorioallantoic placenta was separated into two components: junctional zone and labyrinth zone. The junctional zone was identified by its pale appearance, from the absence of fetal blood, and separated from the labyrinth zone, a richly vascularized tissue, by means of fine forceps and 23-gauge needles. Metrial glands were obtained via dissection of mesometrial uterine tissue immediately adjacent to the conceptus. The metrial gland is a heterogeneous tissue comprised of blood vessels, immune cells, trophoblast cells and fibroblasts (Selye \& McKeown 1935, Pijnenborg et al. 1981, Peel 1989). All tissues were snap-frozen in liquid nitrogen for northern blot analysis. For in situ hybridization, uterine and placental tissues were removed intact without dissection and frozen in dry-icecooled heptane. All tissue samples were stored at $-80{ }^{\circ} \mathrm{C}$ until required for use. Tissue samples were collected from a minimum of three different rats for each data point. The University of Kansas Medical Center Animal Care and Use Committee approved all procedures for handling and experimentation with rodents.

\section{Cell culture models}

Two trophoblast cell culture systems were examined for their ability to express PLP-N. The Rcho-1 trophoblast cell line was derived from a rat choriocarcinoma and is capable of differentiating along the trophoblast giant cell lineage (Faria \& Soares 1991, Peters et al. 2000). Cells were routinely plated at a density of $2-2.5 \times 10^{5}$ cells per $75 \mathrm{~cm}^{2}$ flask in RPMI-1640 culture medium supplemented with $20 \%$ fetal bovine serum (FBS), $50 \mu \mathrm{M}$ 2-mercaptoethanol, $1 \mathrm{mM}$ sodium pyruvate, $100 \mathrm{U} / \mathrm{ml}$ penicillin, and $100 \mu \mathrm{g} / \mathrm{ml}$ streptomycin at the initiation of each experiment. Cells were transferred to differentiation medium (NCTC-135 culture medium supplemented with $10 \%$ horse serum, $50 \mu \mathrm{M} 2$-mercaptoethanol, $1 \mathrm{mM}$ sodium pyruvate, $100 \mathrm{U} / \mathrm{ml}$ penicillin and $100 \mu \mathrm{g} / \mathrm{ml}$ streptomycin) on day 3 of culture and fed every other day with fresh culture medium. Cultures were terminated after $1,4,8$ and 12 days of culture and RNA extracted for northern blot analysis. During 12-day culture, cells proceed from a proliferative to a differentiated state (Hamlin et al. 1994, Peters et al. 2000).

Primary junctional zone cell cultures were established from dissected day 13 rat chorioallantoic placentas as previously described (Lu et al. 1994). Tissues were cut into small pieces with iris scissors and dissociated with Dispase $(4.8 \mathrm{mg} / \mathrm{ml})$ and DNase I $(80 \mathrm{U} / \mathrm{ml})$ for $30 \mathrm{~min}$ at $37^{\circ} \mathrm{C}$ with continuous shaking. The isolated cells were then resuspended in RPMI-1640 culture medium supplemented with $1 \mathrm{mM}$ sodium pyruvate, $50 \mu \mathrm{M}$ $\beta$-mercaptoethanol, $100 \mathrm{U} / \mathrm{ml}$ penicillin, $100 \mu \mathrm{g} / \mathrm{ml}$ streptomycin and 10\% FBS and filtered through a nylon mesh $(70 \mu \mathrm{m})$. The cell suspension was washed and then plated at a density of $2-2.5 \times 10^{6}$ cells per $25 \mathrm{~cm}^{2}$ flask in the supplemented RPMI-1640 culture medium. The purity of the cultures was $>96 \%$ trophoblast. The cells were cultured for 7 days with daily changes of fresh culture medium. At the end of the culture, cells were harvested and RNA extracted for northern blot analysis.

\section{Characterization of the PLP-N $c D N A$}

The NCBI EST database was searched using the translated Basic Local Alignment Search Tool (BLAST) analysis (Altschul et al. 1997) with amino acid sequences for members of the PRL family as queries. Three ESTs possessing homology to rat PLF-RP were identified (UIR-CXO-bws-e-04-0-UI, UI-R-CX0-bxi-h-07-0-UI and UI-R-CXOs-ccv-a-03-0-UI). The three ESTs showed 99\% sequence identity among each other. The UI-R-CXO-bws-e-04-0-UI cDNA was obtained from the University of Iowa Rat Gene Discovery Program and Research Genetics (Huntsville, AL, USA) and used for further analysis. Both strands of the cDNA were sequenced by the Biotechnology Support Facility of the University of Kansas Medical Center. Nucleotide and amino acid sequence comparisons were performed with CLUSTAL W (version 1·8, Thompson et al. 1994). The location of the signal peptide for PLP-N was 
determined by homology and the SignalP software program (version 2.0.b2, Nielsen et al. 1997). The rat PLP-N gene was identified by BLAST analysis (Altschul et al. 1990) of the NCBI rat genome database (http:// www.ncbi.nlm.nih.gov/genome/seq/RnBlast.html) with the rat PLP-N cDNA nucleotide sequence.

\section{Analysis of $m R N A$ expression}

The expression of rat PLP-N mRNAs in the rat was assessed by biochemical and cytochemical procedures.

Northern blot analysis Northern blots were performed as previously described (Faria et al. 1990, Orwig et al. 1997b). RNA was extracted from tissues using TRIzol (Chomczynski \& Sacchi 1987). Total RNA $(20 \mu \mathrm{g})$ was separated on $1 \%$ formaldehyde-agarose gels and transferred to nylon membranes. Blots were probed with $\left[{ }^{32} \mathrm{P}\right]$-labeled cDNAs for PLP-N, PLP-C or PL-II (Dai et al. 2002). Glyceraldehyde-3-phosphate dehydrogenase (G3PDH) cDNA was used as an internal reference to ensure integrity of the RNA samples.

In situ hybridization PRL family mRNAs were detected in placental tissues using non-radioactive in situ hybridization as previously described (Braissant \& Wahli 1998). A plasmid containing the PLP-N cDNA was linearized and used as a template for the synthesis of sense and anti-sense digoxigenin-labeled riboprobes according to the manufacturer's instructions (Roche Molecular Biochemicals, Indianapolis, IN, USA). Tissue sections were air dried and fixed in ice-cold 4\% paraformaldehyde in PBS for $15 \mathrm{~min}$. Pre-hybridization was carried out in a humidified chamber at $50{ }^{\circ} \mathrm{C}$ in $5 \times$ standard saline citrate (SSC), $50 \%$ deionized formamide, $1 \times$ Denhardt's reagent, $10 \%$ dextran sulfate and salmon sperm DNA $(100 \mu \mathrm{g} / \mathrm{ml})$. Hybridizations were performed in the same incubation conditions overnight. Slides were washed in $23 \times \mathrm{SSC}$ at room temperature for $30 \mathrm{~min}$, followed by treatment with RNase-A (100 ng/ml) and additional washes with $23 \times$ SSC for $30 \mathrm{~min}$ at room temperature, followed by washes with $2 \leq \mathrm{SSC}$ for $1 \mathrm{~h}$ at $65^{\circ} \mathrm{C}$ and $0 \cdot 1 \times$ SSC for $1 \mathrm{~h}$ at $65^{\circ} \mathrm{C}$. Tissue sections were blocked for $30 \mathrm{~min}$ and incubated with alkaline phosphataseconjugated anti-digoxigenin antibody (1:500) in blocking buffer (Roche Molecular Biochemicals) for $2 \mathrm{~h}$ at room temperature. Slides were then washed and detection was performed using nitro blue tetrazolium $(250 \mu \mathrm{g} / \mathrm{ml})$ and 5-bromo-4-chloro-3-indolyl-phosphate $(225 \mu \mathrm{g} / \mathrm{ml}$; Roche Molecular Biochemicals).

\section{Immunocytochemistry}

Immunocytochemical analyses were used for the purpose of identifying trophoblast cells. All analyses were performed on $10 \mu \mathrm{m}$ tissue sections prepared with the aid of a cryostat. Rat trophoblast cells were detected using direct immunofluorescence staining with a fluorescein isothiocyanate (FITC)-conjugated mouse monoclonal anti-Pan cytokeratin antibody (clone C-11, Catalog No. F3418; Sigma Chemical Company). The antibody recognizes cytokeratins 4, 5, 6, 8, 10,13 and 18. Cytokeratins 7, 8, 18 and 19 are expressed in rodent trophoblast cells (Hesse et al. 2000, Tamai et al. 2000). Tissue sections were fixed in ice-cold acetone for $10 \mathrm{~min}$ and incubated with $10 \%$ normal rat serum in phosphate buffered saline (PBS, $10 \mathrm{mM} \mathrm{NaH}{ }_{2} \mathrm{PO} 4,150 \mathrm{mM} \mathrm{NaCl}, \mathrm{pH}$ 7·4), for $15 \mathrm{~min}$ and then exposed for $30 \mathrm{~min}$ to FITC-conjugated antibody diluted in PBS (final dilution 1:100). Slides were washed with several changes of PBS for $10 \mathrm{~min}$. Stained tissue sections were examined and images recorded with a Nikon phase/epifluorescence microscope equipped with a CCD camera (Magnafire, Optronics, Goleta, CA, USA).

\section{Results}

\section{Characterization of rat PLP-N $c D N A$}

A new member of the rat PRL family was identified through a search of the NCBI EST database. Three ESTs possessing homology to rat PLF-RP were identified (UI-R-CXO-bws-e-04-0-UI, UI-R-CX0-bxi-h-07-0UI, UI-R-CXOs-ccV-a-03-0-UI) through a translated BLAST search using PLF-RP as a query. The three ESTs showed 99\% sequence identity among each other. The UI-R-CXO-bws-e-04-0-UI cDNA was obtained from the University of Iowa Rat Gene Discovery Program and Research Genetics (Huntsville, AL) and used for further analysis. Both strands of the full-length cDNA were sequenced. The cDNA nucleotide sequence showed no prominent similarity to any other known cDNAs; however, the predicted amino acid sequence exhibited significant similarity to members of the PRL family. According to existing nomenclature, we named the new gene PRLlike protein-N (PLP-N). The rat PLP-N cDNA (GenBank Accession No. AF525159) encodes for a putative 251 amino acid protein (Fig. 1A). A mouse ortholog for rat PLP-N (GenBank Accession No. AF525156) was identified from the public mouse genome assembly (http:// mouse.ensembl.org and http://www.ncbi.nlm.nih.gov/ genome/seq/MmBlast.html) and its cDNA cloned from gestation day 19 mouse placenta (Wiemers et al. 2003). Rat and mouse PLP-N cDNA nucleotide sequences are 90\% identical, whereas their respective predicted amino acid sequences are $82 \%$ identical (Fig. 1A). On the basis of homology with members of the PRL family and the SignalP software program, it was further predicted that rat PLP-N contained a 29 amino acid signal peptide. PLP-N contains four cysteine residues located in positions homologous to cysteines in other members of the PRL family (Fig. 1A and B). A single putative $N$-linked glycosylation site is situated at amino acid 44 of the mature rat PLP-N protein (Fig. 1A,B). Amino acid sequence 
(a)

MPLP-N IPLP-N

MPLP-N rPLP-N

MPLP-N IPLP-N

MPLP-N IPLP-N

MPLP-N IPLP-N

(b)

PLP-I PLP-M

PLP-N

PLF-RP

PLP-F

PRL

PLP-I

PLP-M

PLP-N

PLF-RP

PLP-F

PRL

PLP-I

PLP-M

PLP-N

PLF-RP

PLP-F

PRL

PLP-I

PLP-M

PLP-N

PLF-RP

PLP-F

PRL

PLP-I

PLP-M

PLP-N

PLF-RP

PLP-F

PRL
MNTSLTQLCFWALQILLMSNLLLWEDVVS MHLSLTQQCLWPLQILLVSNLLLWENVAA VPTSDSGLGISELLTEDLFDDAVILSQHING $* \quad * * * * * * \quad * * * * * * * * * * * * * \quad * * * \quad * * * * * * * * * * * * * * * * * * * * *$

LAIETRRIFLSNNFSSDMF ITFTLOFNRHDEFVVNGLNSCHTLPLKSPKTEKEAKRISLP LAIETRRIFLSN NFSSDMFVKFTLQFNRHDEFVVNGLNSCHTSSLKTPKTEKEAKRISLP $\star * * * * * * * * * * * * * * * * * * * \quad * * * * * * * * * * * * * * * * * * * * * \quad * * * * * * * * * * * * * * * *$

DFMNMILSILRAWDNPLHHMETELKSMPGAPFAILARVKDIEVKNKILLDRIMKIAKKGK DFVKMILSILRAWDSPLYHMETELKSMTGAPFS ILARVKEIEVKNKILLKRI IKIAKKVK ** $* * * * * * * * * * * * * * * * * * * * * * * * * * * * * * * * * * * * * * * * * * * * * * *$

YGFEENEVYPAWSELASLQSANEESRFFALYKLSY CLFVDTDKVEHYLKHLX CRYFDGYM HGIEENEEYPVWSELASLQSTNEESRFFALYKMSY CLFVDTDKVEHYLKHLKCRYFDGYM $\star * * * * * * * * * * * * * * * * * * * * * * * * * * * * \star * * * * * * * * * * * * * * * * * * * * * * * *$

MQPVFSQLCS-WVLQLLLVSNVLLWENVYP MPMCPDMEGYNEMF IEDLFDHAIVTAHYTS MOLSITHPCC-WTLRLLLVSNLLLWENVAL VPTCLVRNGRCFASLEEMLERAVGLSEEIS MHLSLTQQCL-WPLQILLVSNLLLWENVAA VPTSDSGLGISELLTEDLFDDAVILSQHIN MPPSLIQSCSSGALLMLLMANLFLWEKVSS APINAS--ETTLNDLKDLFDNATVISGKMA MQLSFSRPRP-WTLLLMVVSNLLLWENVSS GNLNSNETDGDLLLHRGLFDTATRLSODIR -MNSQVSARK-GTLLLLMMSNLLFCQNVQT LPVCSG--GDCQTPLPELFDRVVMLSHYIH

NLTMQMSEEF------------GMHFAHSLGYKSRNSST CHTISLTTPGSNEQIQQTHS KQALQLFTEF------------DNQYAQSKQLINKNFKK CHTSSLELPKPSSTSVQTHP GLAIETRRIFLSNNFSSDMFVKFTLQFNRHDEFVVNGLNSCHTSSLKTPKTEKEAKRISL ELGFAMRKEFF SNSFSSD IFTNI ILDLHKSKENI IKAFNSCHTVPINF PETTEDIRMTSF DLDIEFLRMYAVNEVSEKLYNKHMLEF IEDMDFVVKALTC CHNYSIKTPENLDEAQQIPF TLYTDMF IEF------------DKQYVQDREF IAKA INDCPTSSLATPEDKEQAQKVPP

DVLLKMMIS ILRAWYHPLEHLVHAVATLEGICETMLFKVKEVEEKNQEILEKIKAILVRV ITLLKIASKLLSAWKVPLNDLVNNLPSLKDI HPNILSKARE IEAKSAGLLEGVKS ILIQM PDFVKMILS ILRAWDS PLYHMETELKSMTGAPF S ILARVKE IEVKNKILLKR I IKIAKKV EEFLKMILQTLLAWKDPLQHLVTELSALPGCPYSILSKAKAIEAKNKDLLEYIKRI ISMV NDFPWLILSRMWGWNETSKNLLTILRS IPGMHDDVISLAQAIERKLAELFEYTQS ILTLI EVLLNLILSLVHSWNDPLFQLITGLGGIHEAPDA I SRAKE IEEQNKRLLEGIEKI IGQA

* * * *

YPGAEEN-VYPVWMGLADVRSANELTRHFTLSNLLHCLDSNTDKVATYLEALKCRI I HNN QNGDTEDENYPGWSGLASLQSENEDDRLFAYYNMIRCEGRETQKVETALKMVKCKISNEN KHGIEENEEYPVWSELASLQSTNEESRFFALYKMSY CLFVDTDKVEHYLKHLKCRYFDGY NPAIKENEDYPIWSDLDSLQAADKEIQFFALYMF SFCLRSDLESLDFLVNFLKCLLLYND FGPT-ENVDRS IF SGLEDLKASDEELRFFALCKF SYCLRVDLQTIELYFKLLOCAVNVNS

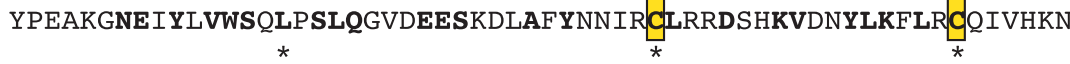

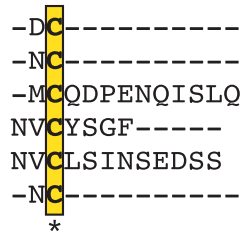


identity of rat PLP-N with other members of the rat PRL family ranged from $26 \%$ to $39 \%$. PLP-I, PLP-M, PLF-RP and PLP-F exhibited the highest level of overall amino acid sequence identity with the newly discovered rat PLP-N (Fig. 1B). The predicted signal peptides of PLP-I, PLP-M and PLP-N were very similar, whereas PLF-RP, PLP-F and PLP-N showed more extensive homology in their mature proteins (Fig. 1B). This latter characteristic was most notable between amino acids $41-52$ of the mature PLP-N protein sequence. This region is homologous with the aromatic domains found in PLF-RP and PLP-F (Sahgal et al. 2000) and with amino acids encoded by exon 3 from members of the PLP-C subfamily (Dai et al. 1996b, 1998, Orwig et al. 1997a). Furthermore PLP-F, PLF-RP and PLP-N were classified into the same subfamily by analysis with the CLUSTAL W software program (Fig. 2). In the mouse, this subfamily includes PLP-N, PLP-F, PLF-RP and two additional PRL family members not yet discovered in the rat, PLP-E and PLP-O (Wiemers et al. 2003). The rat PLP-N gene was identified by BLAST analysis (Altschul et al. 1990) to be located on BAC clone CH230190E4 (GenBank Accession No. Ac133698). This BAC clone is situated on chromosome 17 within the rat PRL family locus. Rat PLP-N possesses a 6-exon-5-intron gene structure similar to that reported for mouse PLP-N (Wiemers et al. 2003). Nucleotide sequences for the rat PLP-N cDNA showed $100 \%$ identity with the corresponding exon sequences of the rat PLP-N gene.

\section{$P L P-N$ northern analyses}

The site(s) of PLP-N expression was assessed by northern blot analyses. A survey of several rat tissues (brain, heart, kidney, liver, muscle, intestine, lung, spleen, testis, ovary, uterus and uteroplacental compartment) indicated that PLP-N mRNA expression was restricted to the uteroplacental compartment (Fig. 3). A more systematic examination of expression in the uteroplacental compartment was performed. PLP-N mRNA levels were estimated in the junctional and labyrinth zones of the chorioallantoic placenta and in the metrial gland (Fig. 4). PLP-N mRNA was low or undetectable in all placental tissues (Fig. 4). In contrast, PL-II mRNA was strongly expressed in both the junctional and labyrinth zones of the chorioallantoic placenta, consistent with earlier observations (Deb et al.

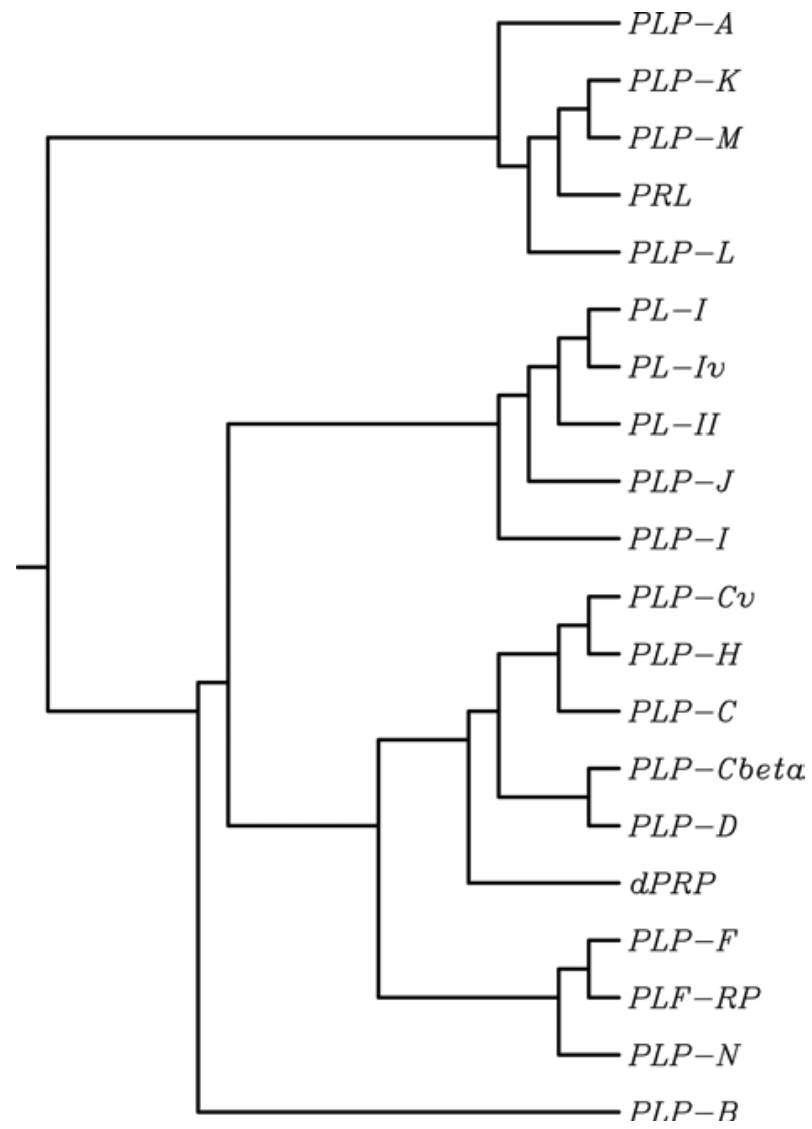

Figure 2 The rat PRL family tree. Comparison of the 20 paralogous rat PRL family CDNAs and phylogenetic tree construction were performed using CLUSTAL W (Version 2.0) software program (Thompson et al. 1994). GenBank Accession Nos. mouse PLP-N [AF525156] and rat PRL family members: PLP-A [M13750], PLP-K [AF234635], PLP-M [AF226608], PRL [V01249], PLP-L [AB022883], PL-I [D21103], PL-IV [U32679], PL-II [M13749], PLP-J [AB019945], PLP-I [AF526270], PLP-CV [U93351], PLP-H [AB009889], PLP-C [M76537], PLP-C beta, PLP-D [AB000107], dPRP [L06441], PLP-F [AF139808], PLF-RP [AF139809], PLP-N [AF525159], and PLP-B [M31155]. PRL, prolactin; $\mathrm{PL}$, placental lactogen; PLF-RP, proliferin related protein; PLP, PRL-like protein; D/tPRP, decidual PRL-related protein.

1991a, Dai et al. 2002). We further examined PLP-N and PL-II expression in cells of the trophoblast cell lineage. The Rcho-1 trophoblast cell line is a useful model for

Figure 1 Amino acid sequence comparisons of rat PLP-N with mouse PLP-N and other members of the rat PRL family. GenBank Accession Nos for mouse PLP-N [AF525156] and rat PRL family members: [AF226608], PRL [V01249], PLP-I [AF526270], PLP-F [AF139808], PLF-RP [AF139809], and PLP-N [AF525159]. PRL, prolactin; PLF-RP, proliferin related protein; PLP, PRL-like protein. (a) Amino acid alignments of rat PLP-N and mouse PLP-N. An arrow indicates the predicted signal peptide cleavage sites (Ala ${ }^{-1}$ and $\mathrm{Val}^{+1}$ ). The identities of these sites as cleavage sites is based on the SignalP software program (Nielsen et al. 1997) and homologies with other members of the PRL family. Conserved cysteine residues are shown as yellow shaded boxes. Putative $N$-linked glycosylation sites are denoted as purple shaded boxes. Asterisks below the sequences denote identity. (b) Amino acid alignments of rat PRL family members: PLP-N, PLP-I, PLP-M, PLF-RP, PLP-F and PRL. An arrow indicates the predicted signal peptide cleavage sites (as in (a)). Conserved cysteine residues are shown as yellow shaded boxes. Putative $N$-linked glycosylation sites are denoted as purple shaded boxes. Amino acids identical to rat PLP-N are shown in bold. Asterisks below the sequences denote identity. 


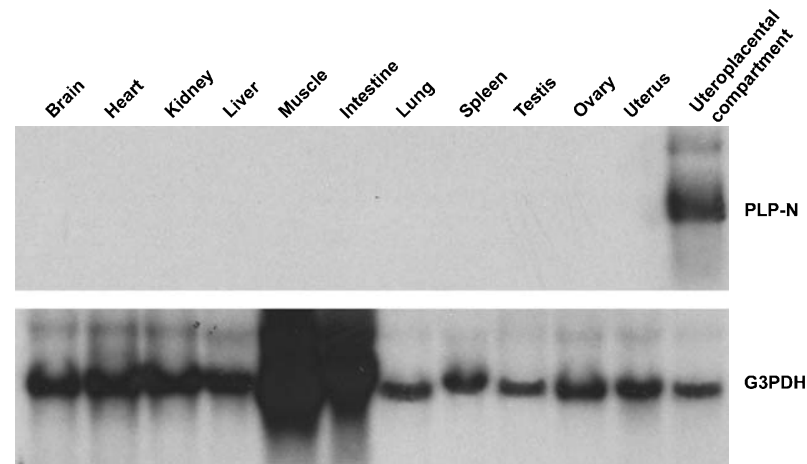

Figure 3 Tissue survey of PLP-N mRNA distribution. Total RNA was collected from brain, heart, kidney, liver, muscle, intestine, lung, spleen, testis, ovary, uterus from a non-pregnant rat and the uteroplacental compartment from the gestation day 20 rat. Relative concentrations of PLP-N were determined by northern blot analysis. G3PDH was used as a control to demonstrate loading accuracy and the integrity of the RNA.

investigating the trophoblast giant cell lineage (Faria \& Soares 1991, Peters et al. 2000). We investigated PLP-N and PL-II mRNA levels in proliferating and differentiating Rcho-1 trophoblast cells. PL-II mRNA was abundantly expressed in the differentiating trophoblast cells, whereas PLP-N mRNA was not detectable (Fig. 4). The metrial gland harvested from day 20 of gestation was a rich source of PLP-N mRNA (Fig. 4). Metrial gland PLP-N expression was initiated between day 14 and 16 and increased as gestation progressed (Fig. 5).

In some of the PLP-N northern blots a higher molecular weight hybridizing band was detected. The identity of the larger hybridizing band was not determined. The larger hybridizing band could be an incompletely or alternatively processed PLP-N transcript.

Collectively, the northern blot experiments indicated that the metrial gland was a prominent source of PLP-N; and the chorioallantoic placenta and the trophoblast giant cell lineage were not major contributors to PLP-N synthesis. However, these experiments did not lead to the identification of the cellular source of PLP-N.

In situ localization of PLP-N

The major source of PLP-N, the metrial gland, contains a mixture of cell types, including immune cells, stromal

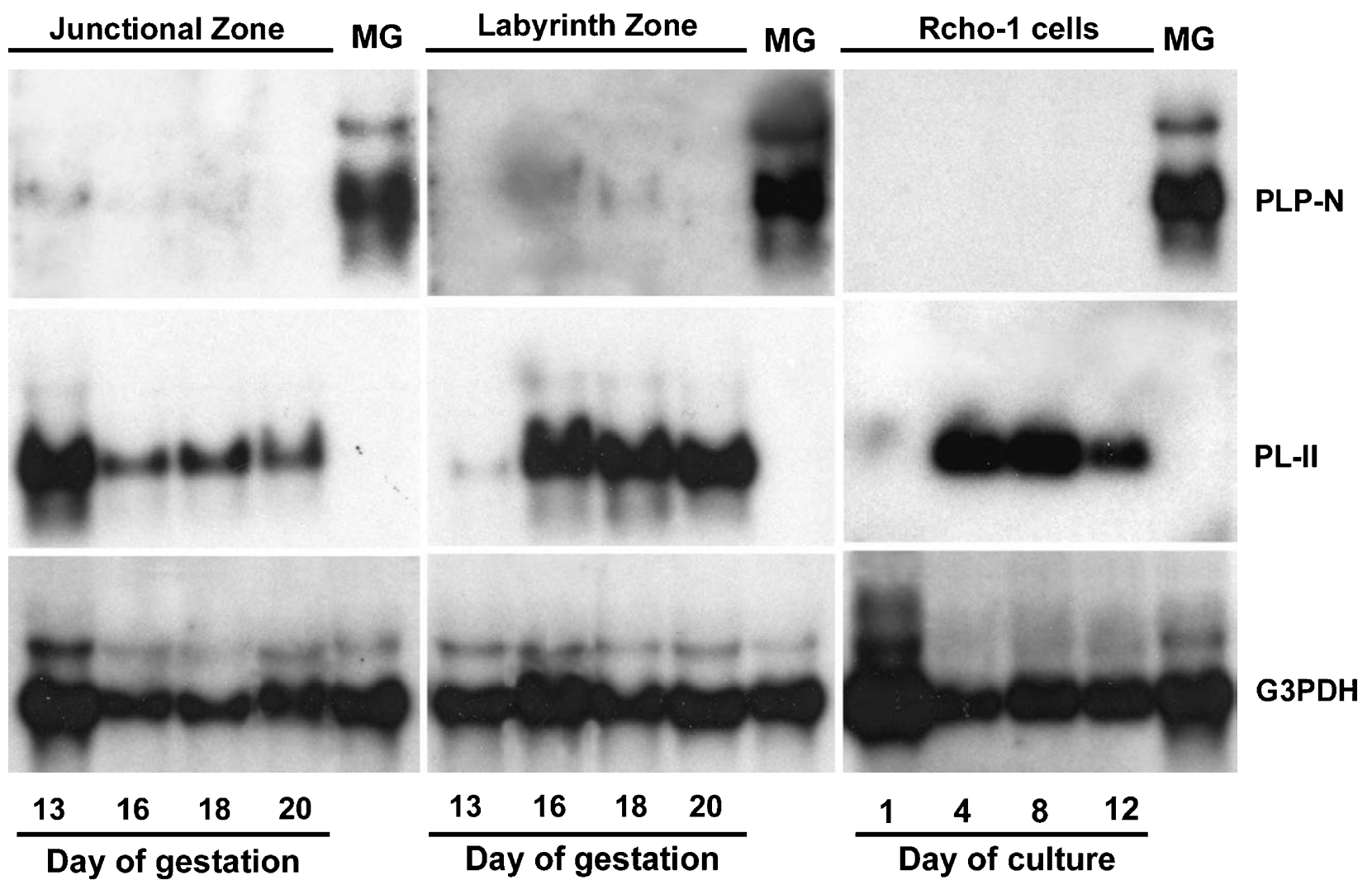

Figure 4 Expression of PLP-N and PL-II mRNAs in the rat placenta and in rat trophoblast cells. Total RNA was collected from junctional and labyrinth zones of the chorioallantoic placenta (days 13, 16, 18 and 20 of gestation) and the Rcho- 1 trophoblast cells during various stages of differentiation (days 1, 4, 8 and 12 of culture). Relative concentrations of PLP-N and PL-II were determined by northern blot analysis. G3PDH was used as a control to demonstrate loading accuracy and the integrity of the RNA. Metrial gland (MG; day 20 of gestation) total RNA served as a positive control. 


\section{Metrial gland}

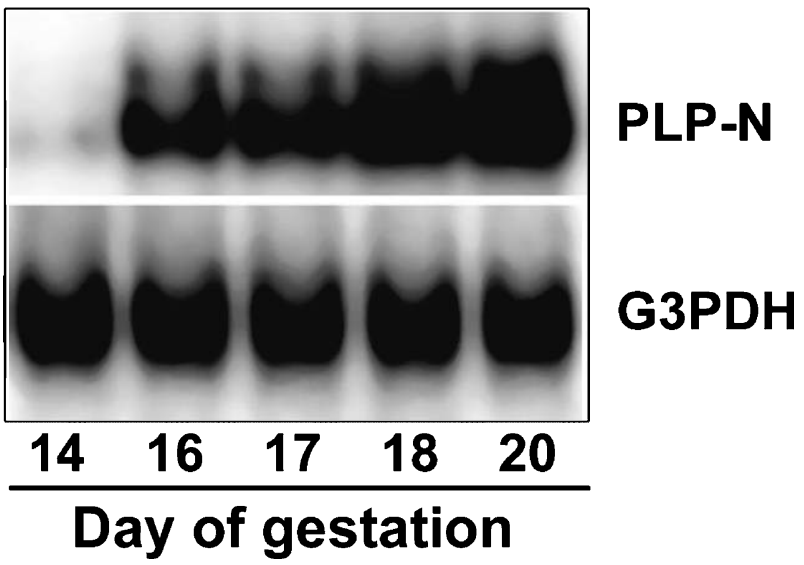

Figure 5 Expression of PLP-N in the rat metrial gland during pregnancy. Total RNA was collected from metrial glands (days 14, $16,17,18$ and 20 of gestation). Relative concentrations of PLP-N were determined by northern blot analysis. G3PDH was used as a control to demonstrate loading accuracy and the integrity of the RNA.

cells, smooth muscle cells, endothelial cells and trophoblast cells (Pijnenborg et al. 1981, Peel 1989, Stewart \& Mitchell 1992). In situ hybridization analyses were performed with sense and antisense probes in order to determine the cellular site of PLP-N synthesis. Sense probes did not provide detectable hybridization in any of the tissues investigated. Antisense probes localized PLP-N mRNA to migratory trophoblast cells. At day 14 of gestation, endovascular trophoblast cells possessed PLP-N mRNA (Fig. 6B,D). As gestation progressed, extraplacental migratory trophoblast cells positive for PLP-N mRNA were abundant. Both endovascular and interstitial migratory trophoblasts situated throughout the metrial gland expressed PLP-N mRNA (Figs 6B,D,7B-D). Red arrowheads in Figs 6 and 7 are directed toward endovascular trophoblast cells and red arrows point towards interstitial trophoblast cells. Cells expressing cytokeratin and PLP-N possess an overlapping spatial distribution within the metrial gland (Fig. 7A). Cytokeratin immunoreactivity has previously been used as a means of identifying cells of the trophoblast lineage within the uteroplacental compartment (Hunt \& Soares 1988, Kruse et al. 1999).

In vitro differentiation of PLP-N producing cells

There is a spatial continuum of trophoblast cells from the junctional zone of the chorioallantoic placenta to the metrial gland. This observation suggests that the junctional zone contains a population of cells capable of differentiating into the trophoblast cells. Consequently, primary cell cultures were established from the junctional zone of the gestation day 13 chorioallantoic placenta according to procedures previously described by members of our laboratory ( $\mathrm{Lu}$ et al. 1994). The junctional zone trophoblast cells were cultured for 7 days and harvested for RNA analysis. As PLP-N mRNA is restricted to migratory trophoblast cells, we used PLP-N mRNA as a means of identifying migratory trophoblast cells. PLP-N mRNA expression was minimal in gestation day 13 or day 18 junctional zone dissected tissue, but was readily detected in the junctional zone cells after 7 days of culture (Fig. 8). The cultured gestation day 13 junctional zone cells also expressed PLP-C mRNA, a member of the PRL family and marker of spongiotrophoblast cell development (Deb et al. 1991b,c, Lu et al. 1994). PLP-C mRNA was not expressed in the metrial gland (Fig. 8). Thus junctional zone trophoblast cells showed the capacity to differentiate into both spongiotrophoblast cells and migratory trophoblast cells of the metrial gland.

\section{Discussion}

To date, 20 PRL-related genes have been identified in the rat. Each possesses the prototypical PRL structural backbone. In this report, evidence is presented for the discovery of a new member of the rat PRL family through mining of the NCBI EST database. On the basis of existing nomenclature, the new member was named PRL-like protein-N (PLP-N). Structurally, PLP-N exhibits significant similarities with other members of the PRL family. It is uniquely expressed in a population of migratory trophoblast cells that populate the metrial gland during the last trimester of pregnancy.

The PRL family represents a species-specific expansion of genes involved in adaptations to pregnancy (Mouse Genome Sequencing Consortium 2002). Although there are some notable differences, the PRL family genes of the mouse and rat, including PLP-N, exhibit striking similarities. A mouse ortholog for rat PLP-N has been recently described (Wiemers et al. 2003). Structures of the mouse and rat PLP-N gene, mRNA and proteins are very similar. Tissue expression patterns for mouse and rat PLP-N show some differences. In the mouse, PLP-N is expressed in trophoblast cells of the chorioallantoic placenta and in migratory trophoblast cells, whereas in the rat, PLP-N is only expressed in migratory trophoblast cells (present study). The significance of these two distinct patterns of expression is unknown. The human PRL family consists of a single member, PRL, whereas other species such as the cow possesses a multi-member PRL family with an independent pattern of expansion (Schuler \& Kessler 1992, Soares \& Linzer 2001). Orthogs for PLP-N have not been identified in the human, the cow or any species other than the mouse and rat.

PLP-N shares structural similarities with other members of the PRL family. These include an extensive amino acid 

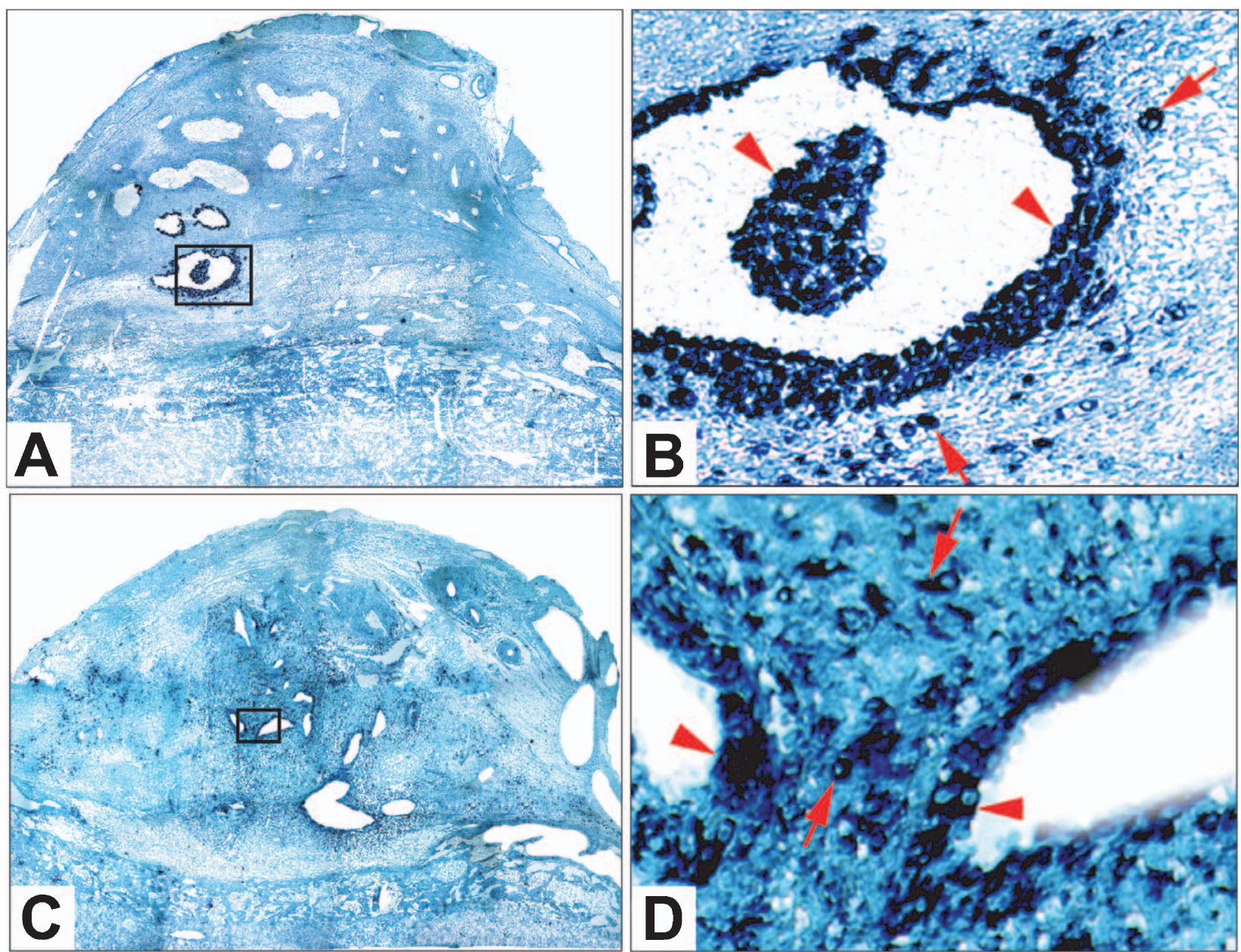

Figure 6 Cell- and tissue-specific localization of PLP-N in the rat conceptus. Conceptuses were isolated on days 14 and 20 of gestation. The in situ detection of mRNA expression was performed on frozen tissue sections. cDNAs were used as templates for the synthesis of digoxigenin-labeled sense and antisense RNA probes. (A) Tissue section from the mesometrial region of gestation day 14 conceptus; (B) tissue section from the boxed area shown in (A); (C) tissue section from the mesometrial region of gestation day 20 conceptus; (D) tissue section from the boxed area shown in $(C)$. Original magnifications: $(A),(C) \times 20$; $(B) \times 150$; (D) $\times 300$. Red arrowheads indicate the location of endovascular trophoblast cells and red arrows show the location of interstitial trophoblast cells. Please note that sense probes did not provide detectable hybridization in any of the tissues investigated.

sequence identity within the predicted signal peptides of PLP-I and PLP-M. The mature PLP-N protein demonstrates considerable homology to PLF-RP and PLP-F, including conservation of the aromatic domain found in PLF-RP, PLP-F and members of the PLP-C subfamily (Sahgal et al. 2000). This domain is enriched in aromatic amino acids and is encoded by a short exon situated between exons II and III of the prototypical PRL gene structure, as is found in several members of the PLP-C subfamily (Dai et al. 1996b, 1998, Orwig et al. 1997a) and in mouse PLP-N (Wiemers et al. 2003). The biological significance of the aromatic domain is not known. Some insights about the biology of PLP-N may be gained from research on the physiology of PLF-RP and PLP-F: PLF-RP targets endothelial cells, where it regu- lates angiogenesis (Jackson et al. 1994, Bengtson \& Linzer 2000, Regulier et al. 2001), whereas PLP-F modulates hematopoiesis (Zhou et al. 2002). Whether PLP-N influences endothelial or hematopoietic cells remains to be determined.

Migratory trophoblast cells synthesize PLP-N. These cells exist within the chorioallantoic placenta at midgestation and leave the chorioallantoic placenta during the last week of gestation. At midgestation, migratory trophoblasts are primarily situated within blood vessels, as best typified by endovascular trophoblast cells lining the central placental artery (Bridgman 1949, Pijnenborg et al. 1981, Zybina \& Zybina 2000, Zybina et al. 2000). As gestation advances, endovascular trophoblast cells are located within mesometrial uterine blood vessels located outside the 

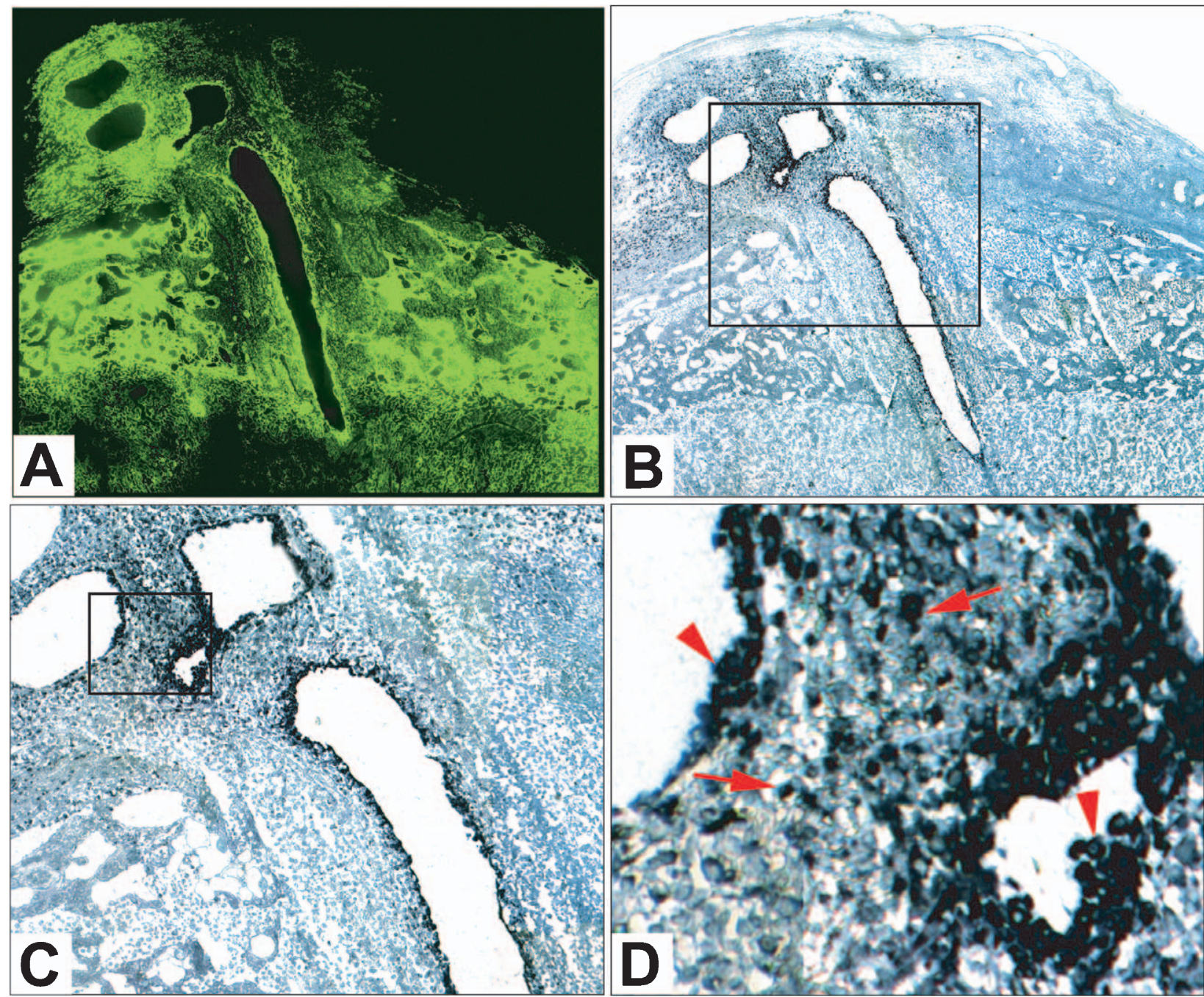

Figure 7 Identification of migratory PLP-N-expressing trophoblast cells. Conceptuses were isolated at day 16 of gestation and $10 \mu \mathrm{m}$ cryosections were prepared. (A) Cytokeratin immunolocalization within the mesometrial conceptus. (B-D) In situ detection of PLP-N mRNA expression. PLP-N cDNA was used as template for the synthesis of digoxigenin-labeled antisense RNA probes. (C) Section corresponding to the boxed area shown in (B). (D) Section corresponding to the boxed area shown in (C). Original magnifications: (A), (B) $\times 20$; (C) $\times 45$; (D) $\times 200$. Red arrowheads indicate the location of endovascular trophoblast cells and red arrows show the location of interstitial trophoblast cells. Please note that sense probes did not provide detectable hybridization in any of the tissues investigated.

chorioallantoic placenta. In addition, beginning between days 14 and 15 of gestation in the rat, interstitial trophoblast cells systematically leave the junctional zone of the chorioallantoic placenta (Bridgman 1949, Pijnenborg et al. 1981). They penetrate through the mesometrial decidua and colonize the mesometrial triangle, forming intimate relationships with the uterine vasculature. This mesometrial structure is referred to as the metrial gland (Selye \& McKeown 1935). The metrial gland represents the major site of blood flowing to the placenta and, ultimately, to the fetus. The biological activities of PLP-N are not known. On the basis of the localization of this cytokine within migratory trophoblast cells of the metrial gland, we postulate that it may target cells within the metrial gland, including myometrial or vascular smooth muscle cells, immune cells, or uterine stromal cells during the last trimester of gestation. PLP-N is uniquely expressed only in endovascular and interstitial migratory trophoblast cells, and thus represents a useful biological marker for these cell types (present study). These migratory trophoblast cells appear to arise from the junctional zone of the chorioallantoic placenta (present study). The factor(s) underlying trophoblast cell 'decisions' to leave or remain within the rat chorioallantoic placenta are not known. Human trophoblast cell migration is regulated by an interplay of locally acting cytokines and growth factors, including 


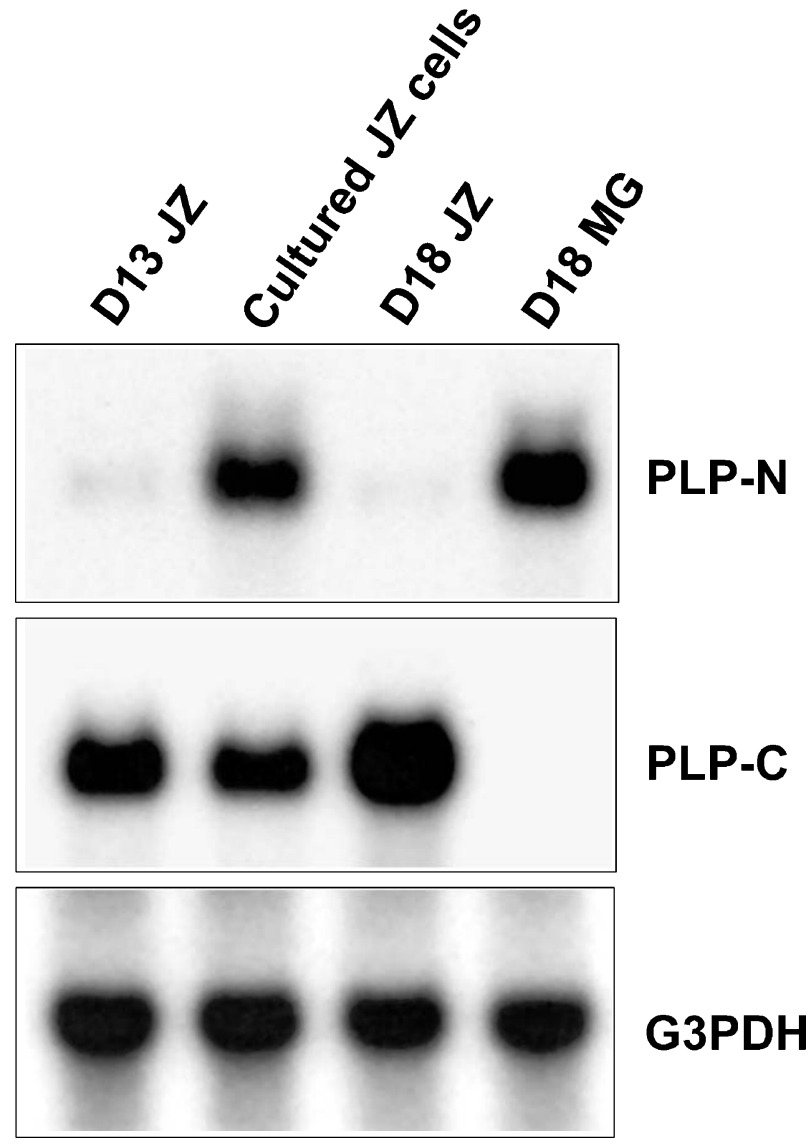

Figure 8 PRL family gene expression in junctional zone trophoblast cell cultures. Total RNA was isolated from gestation day 13 junctional zone tissue (D13 JZ), gestation day 13 junctional zone cells cultured for 7 days (JZ cells), gestation day 18 junctional zone (D18 JZ) and gestation day 18 metrial gland (D18 MG). Relative levels of PLP-N and PLP-C were determined by northern blot analysis. G3PDH was used as a control to demonstrate loading accuracy and the integrity of the RNA.

colony stimulating factor-I, epidermal growth factor and insulin-like growth factor-I (Bass et al. 1994, Hamilton et al. 1998, Aplin et al. 2000, Nasu et al. 2000). We propose that trophoblast cell PLP-N expression may be an effective tool for monitoring the differentiation of the trophoblast cell invasive phenotype.

In summary, a new member of the PRL family, PLP-N, has been discovered. PLP-N expression uniquely identifies migratory trophoblast cells, including those localized to the metrial gland.

\section{Acknowledgements}

We would like to thank Davin Watne and Jared T Soares for assistance with the preparation of some of the figures.

\section{Funding}

This work was supported by grants from the National Institutes of Health (HD020676, HD029797, HD033994, HD037123, HD039878). Rupasri Ain was supported by a postdoctoral fellowship from the American Heart Association.

\section{References}

Ain R, Müller H, Sahgal N, Dai G \& Soares MJ 2002 Uteroplacental prolactin family: immunological regulators of viviparity. Neuroimmune Biology 2 187-202.

Altschul SF, Gish W, Miller W, Myers EW \& Lipman DJ 1990 Basic local alignment search tool. Journal of Molecular Biology 215 403-410.

Altschul SF, Madden TL, Schaffer AA, Zhang J, Zhang Z, Miller W \& Lipman DJ 1997 Gapped BLAST and PSI-BLAST: a new generation of protein database search programs. Nucleic Acids Research 25 3389-3402.

Aplin JD, Lacey H, Haigh T, Jones CJP, Chen CP \& Westwood M 2000 Growth factor-extracellular matrix synergy in the control of trophoblast invasion. Biochemical Society Transactions 28 199-202.

Bass KE, Morrish D, Roth I, Bhardwaj D, Taylor R, Zhou Y \& Fisher SJ 1994 Human cytotrophoblast invasion is up-regulated by epidermal growth factor: evidence that paracrine factors modify this process. Developmental Biology 164 550-561.

Bengtson NW \& Linzer DIH 2000 Inhibition of tumor growth by the antiangiogenic placental hormone, proliferin-related protein. Molecular Endocrinology 14 1934-1943.

Bittorf T, Jaster R, Soares MJ, Seiler J, Brock J, Friese K \& Müller H 2000 Induction of erythroid proliferation and differentiation by a trophoblast-specific cytokine involves activation of the JAK/STAT pathway. Journal of Molecular Endocrinology 25 253-262.

Braissant O \& Wahli W 1998 A simplified in situ hybridization protocol using non-radioactively labeled probes to detect abundant and rare mRNAs on tissue sections. Biochemica 1 10-16.

Bridgman J 1949 A morphological study of the development of the placenta of the rat. II. An histological and cytological study of the development of the chorioallantoic placenta of the white rat. Journal of Morphology 83 195-224.

Campbell WJ, Deb S, Kwok SCM, Joslin JA, \& Soares MJ 1989 Differential expression of placental lactogen-II and prolactin-like protein-A in the rat chorioallantoic placenta. Endocrinology 125 1565-1574.

Chomczynski P \& Sacchi N 1987 Single-step method of RNA isolation by acid guanidinium thiocyanate-phenol-chloroform extraction. Analytical Biochemistry 162 156-159.

Cohick CB, Dai G, Xu L, Deb S, Kamei T, Levan G, Szpirer C, Szpirer J, Kwok SCM \& Soares MJ 1996 Placental lactogen-I variant utilizes the prolactin receptor signaling pathway. Molecular and Cellular Endocrinology 116 49-58.

Cooke NE, Szpirer C \& Levan G 1986 The related genes encoding growth hormone and prolactin have been dispersed to chromosomes 10 and 17 in rat. Endocrinology 119 2451-2454.

Corbacho AM, Martinez de la Escalera G \& Clapp C 2002 Roles of prolactin and related members of the prolactin/growth hormone/placental lactogen family in angiogenesis. Journal of Endocrinology 173 219-238.

Dai G, Imagawa W, Liu B, Szpirer C, Levan G, Kwok SCM \& Soares MJ 1996a Rcho-1 trophoblast cell placental lactogens: complementary DNAs, heterologous expression, and biological activities. Endocrinology 137 5020-5027. 
Dai G, Liu B, Levan G, Szpirer C, Kwok SCM \& Soares MJ 19966 Prolactin-like protein-C variant: complementary DNA, unique six exon gene structure, and trophoblast cell-specific expression. Endocrinology 137 5009-5019.

Dai G, Chapman BM, Liu B, Orwig KE, Wang D, White RA, Preuett B \& Soares MJ 1998 A new member of the mouse prolactin (PRL)-like protein-C subfamily, PRL-like protein-C $\alpha$ : structure and expression. Endocrinology 139 5157-5163.

Dai G, Wang D, Liu B, Kasik JW, Müller H, White RA, Hummel GS \& Soares MJ 2000 Three novel paralogs of the rodent prolactin gene family. Journal of Endocrinology 166 63-75.

Dai G, Lu L, Tang S, Peal MJ \& Soares MJ 2002 The prolactin family miniarray: a tool for evaluating uteroplacental/trophoblast endocrine phenotypes. Reproduction 124 755-765.

Deb S, Faria T, Roby KF, Larsen D, Kwok SCM, Talamantes F \& Soares MJ 1991a Identification and characterization of a new member of the placental prolactin family: placental lactogen-I variant. Journal of Biological Chemistry 266 1605-1610.

Deb S, Roby KF, Faria TN, Larsen D \& Soares MJ $1991 b$ Identification and immunochemical characterization of a major placental secretory protein related to the prolactin-growth hormone family, prolactin-like protein-C. Endocrinology 128 3066-3072.

Deb S, Roby KF, Faria TN, Szpirer C, Levan G, Kwok SCM \& Soares MJ 1991c Molecular cloning and characterization of prolactin-like protein-C complementary deoxyribonucleic acid. Journal of Biological Chemistry 266 23027-23032.

Faria TN \& Soares MJ 1991 Trophoblast cell differentiation: establishment, characterization, and modulation of a rat trophoblast cell line expressing members of the placental prolactin family. Endocrinology 129 2895-2906.

Faria TN, Deb S, Kwok SCM, Talamantes F \& Soares MJ 1990 Ontogeny of placental lactogen-I and placental lactogen-II expression in the developing rat placenta. Developmental Biology 141 279-291.

Goffin V, Binart N, Touraine P \& Kelly PA 2002 Prolactin: the new biology of an old hormone. Annual Review of Physiology 64 $47-67$.

Hamilton GS, Lysiak JJ, Watson AJ \& Lala PK 1998 Effects of colony stimulating factor- 1 on human extravillous trophoblast growth and invasion. Journal of Endocrinology 159 69-77.

Hamlin GP, Lu X-J, Roby KF \& Soares MJ 1994 Recapitulation of the pathway for trophoblast giant cell differentiation in vitro stage-specific expression of members of the prolactin gene family. Endocrinology 134 2390-2396.

Hesse M, Franz T, Tamai Y, Taketo MM \& Magin TM 2000 Targeted deletion of keratins 18 and 19 leads to trophoblast fragility and early embryonic lethality. EMBO Journal 19 5060-5070.

Hunt JS \& Soares MJ 1988 Expression of histocompatibility antigens, transferring receptors, intermediate filaments, and alkaline phosphatase by in vitro cultured rat placental cells and rat placental cells in situ. Placenta 9 159-171.

Jackson D, Volpert OV, Bouck N \& Linzer DIH 1994 Stimulation and inhibition of angiogenesis by placental proliferin and proliferin-related protein. Science 266 1581-1584.

Kruse A, Hallmann R \& Butcher EC 1999 Specialized patterns of vascular differentiation antigens in the pregnant mouse uterus and the placenta. Biology of Reproduction 61 1393-1401.

Lin J \& Linzer DIH 1999 Induction of megakaryocyte differentiation by a novel pregnancy-specific hormone. Journal of Biological Chemistry 274 21485-21489.

Lu X-J, Deb S \& Soares MJ 1994 Spontaneous differentiation of trophoblast cells along the spongiotrophoblast pathway: expression of the placental prolactin gene family and modulation by retinoic acid. Developmental Biology 163 86-97.
Mouse Genome Sequencing Consortium 2002 Initial sequencing and comparative analysis of the mouse genome. Nature $\mathbf{4 2 0}$ $520-562$

Müller H, Liu B, Croy BA, Head JR, Hunt JS, Dai G \& Soares MJ 1999 Uterine natural killer cells are targets for a trophoblast cell-specific cytokine, prolactin-like protein-A. Endocrinology 140 2711-2720.

Nasu K, Zhou Y, McMaster MT \& Fisher SJ 2000 Upregulation of human cytotrophoblast invasion by hepatocyte growth factor. Journal of Reproduction and Fertility 55 (Suppl) 73-80.

Nielsen H, Engelbrecht J, Brunak S \& von Heijne G 1997 Identification of prokaryotic and eukaryotic signal peptides and prediction of their cleavage sites. Protein Engineering 10 1-6.

Orwig KE, Dai G, Rasmussen CA \& Soares MJ 1997 a Decidual/trophoblast prolactin related protein: characterization of gene structure and cell-specific expression. Endocrinology 138 2491-2500.

Orwig KE, Ishimura R, Müller H, Liu B \& Soares MJ 1997 b Identification and characterization of a mouse homolog for decidual/trophoblast prolactin-related protein. Endocrinology 139 $5511-5517$.

Peel S 1989 Granulated metrial gland cells. Advances in Anatomy, Embryology and Cell Biology 115 1-112.

Peters TJ, Chapman BM \& Soares MJ 2000 Trophoblast differentiation: an in vitro model for trophoblast giant cell development. In: Developmental Protocols, pp 301-311. Eds RS Tuan \& CW Lo. Totowa, New Jersey: Humana Press.

Pijnenborg R, Robertson WB, Brosens I \& Dixon G 1981 Trophoblast invasion and the establishment of haemochorial placentation in man and laboratory animals. Placenta 2 71-92.

Regulier E, Paul S, Marigliano M, Kintz J, Poitevin Y, Ledoux C, Roecklin D, Cauet G, Calenda V \& Homann HE 2001 Adenovirus-mediated delivery of antiangiogenic genes as an antitumor approach. Cancer Gene Therapy 8 45-54.

Roby KF, Deb S, Gibori G, Szpirer C, Levan G, Kwok SCM \& Soares MJ 1993 Decidual prolactin-related protein. Identification, molecular cloning, and characterization. Journal of Biological Chemistry 268 3136-3142.

Sahgal N, Knipp GT, Liu B, Chapman BM, Dai G \& Soares MJ 2000 Identification of two new nonclassical members of the rat prolactin family. Journal of Molecular Endocrinology 24 95-105.

Schuler L \& Kessler MA 1992 Bovine placental prolactin-related hormones. Trends in Endocrinology and Metabolism 3 334-338.

Selye H \& McKeown T 1935 Studies on the physiology of the maternal placenta in the rat. Proceedings of the Royal Society of London, Biology 119 1-31.

Shah P, Sun Y, Szpirer C \& Duckworth ML 1998 Rat placental lactogen II gene: characterization of gene structure and placental specific expression. Endocrinology 139 967-973

Soares MJ \& Linzer DIH 2001 Rodent prolactin family and pregnancy. In: Prolactin, pp 139-167. Ed ND Horseman. Norwell MA: Kluwer Academic Publishers.

Stewart IJ \& Mitchell BS 1992 Macrophages and other endocytic cells in the mouse uterus during the second half of pregnancy and into the postpartum period. Journal of Anatomy 181 119-126.

Tamai Y, Ishikawa T, Bosl MR, Mori M, Nozaki M, Baribault H, Oshima RG \& Taketo MM 2000 Cytokeratins 8 and 19 in the mouse placental development. Journal of Cell Biology 151 563-572.

Thompson JD, Higgins DG \& Gibson TJ 1994 CLUSTAL W: improving the sensitivity of progressive multiple sequence alignment through sequence weighting, positions-specific gap penalties and weight matrix choice. Nucleic Acids Research 22 4673-4680.

Wang D, Ishimura R, Walia DS, Müller H, Dai G, Hunt JS, Lee NA, Lee JJ \& Soares MJ 2000 Eosinophils are cellular targets of the novel uteroplacental heparin-binding cytokine, decidual/trophoblast prolactin-related protein. Journal of Endocrinology 167 15-29. 
Wiemers DO, Shao L-J, Ain R, Dai G \& Soares MJ 2003 The mouse prolactin gene family locus. Endocrinology 144 313-325.

Yu-Lee L-Y 2002 Prolactin modulation of immune and inflammatory responses. Recent Progress in Hormone Research $\mathbf{5 7}$ 435-455.

Zhou B, Lum HE, Lin J \& Linzer DIH 2002 Two placental hormones are agonists in stimulating megakaryocyte growth and differentiation. Endocrinology 143 4281-4286.

Zybina TG \& Zybina EV 2000 Genome multiplication in the tertiary giant trophoblast cells in the course of their endovascular and interstitial invasion into the rat placenta decidua basalis. Early Pregnancy: Biology and Medicine 4 99-109.

Zybina EV, Zybina TG \& Stein GI 2000 Trophoblast cell invasiveness and capability for the cell and genome reproduction in rat placenta. Early Pregnancy: Biology and Medicine 4 39-57.

Received in final form 30 July 2003

Accepted 4 August 2003

Made available online as an

Accepted Preprint 7 August 2003 